\title{
Perbandingan Luaran dan Biaya Penutupan Defek Septum Ventrikel Perimembran secara Transkateter dan Pembedahan
}

Liku Satriani, Audrey, Piprim B Yanuarso, Mulyadi M Djer

Departemen Ilmu Kesehatan Anak Fakultas Kedokteran Universitas Indonesia/Rumah Sakit Cipto Mangunkusumo, Jakarta

\begin{abstract}
Latar belakang. Terapi baku emas dalam penutupan defek septum ventrikel (DSV) adalah pembedahan. Prosedur pembedahan mempunyai morbiditas yang terkait dengan torakotomi, pintasan jantung paru, komplikasi prosedur, jaringan parut bekas operasi, dan trauma psikologis. Oleh karena itu, timbul usaha pendekatan transkateter untuk menutup DSV yang bersifat relatif kurang invasif. Tujuan. Mengetahui perbandingan hasil penutupan DSV perimembran, komplikasi prosedur, lama rawat di rumah sakit, dan total biaya prosedur antara prosedur transkateter dengan prosedur pembedahan.

Metode. Penelitian retrospektif analitik dengan data berupa rekam medis pasien anak dengan DSV perimembran yang datang ke Pelayanan Jantung Terpadu Rumah Sakit dr. Cipto Mangunkusumo dan dilakukan penutupan defek dengan salah satu prosedur dalam periode Januari 2010-Desember 2013.

Hasil. Didapat 69 kasus anak dengan DSV perimembran, terdiri atas 39 kasus dengan prosedur pembedahan dan 30 kasus dengan prosedur transkateter. Prosedur pembedahan dan prosedur transkateter mempunyai tingkat keberhasilan yang serupa $(89,7 \%$ vs $96,7 \%$, $\mathrm{p}=0,271)$. Prosedur pembedahan mempunyai komplikasi yang lebih banyak dibandingkan prosedur transkateter $(46,7 \%$ vs $7,7 \%$, $\mathrm{p}<0,001)$. Prosedur pembedahan juga mempunyai lama rawat di rumah sakit yang lebih panjang dibandingkan prosedur transkateter ( 8 hari vs 3 hari, $\mathrm{p}<0,0001$ ), dan semua prosedur pembedahan membutuhkan perawatan di ruang rawat intensif. Tidak ada perbedaan total biaya antara prosedur transkateter dengan prosedur pembedahan (Rp. 55.032 .636 vs Rp. 58.593.320 p=0,923).

Kesimpulan. Prosedur penutupan DSV perimembran secara transkateter mempunyai efektivitas dan biaya yang sama dengan prosedur pembedahan dan mempunyai komplikasi yang lebih sedikit serta lama rawat di rumah sakit yang lebih pendek.
\end{abstract}

Sari Pediatri 2015;17(1):9-16.

Kata kunci: DSV perimembran, perbandingan, transkateter, pembedahan

\section{Comparison of Outcome and Cost of Transcatheter and Surgical Closure of Perimembrane Ventricular Septal Defect}

Liku Satriani, Audrey, Piprim B Yanuarso, Mulyadi M Djer

Background. Surgery has become standard therapy for ventricular septal defect (VSD) closure, but it has significant morbidity related to sternotomy, cardiopulmonary bypass, complication, residual scar, and trauma. Non-surgical and less invasive approaches with transcatheter device were developed to occlude VSD.

Objectives. To compare efficacy, complication, length of hospital stay and total cost of perimembrane VSD closure procedure between transcatheter closure and surgery.

Methods. A retrospective analysis was performed on children with perimembran VSD admitted to Cardiology Center of Dr. Cipto Mangunkusumo Hospital from January 2010-December 2013. The patients received transcatheter closure or surgical closure. Data were obtained from medical record.

Results. A total of 69 perimembrane VSD cases were included in study, consisted of 39 cases underwent transcatheter closure and 30 cases underwent surgical closure. The efficacy of both procedur were not statistically different $(89.7 \%$ vs $96.7 \%, p=0.271)$. However, surgery procedure had more complications than transcatheter closure ( $46.7 \%$ vs $7.7 \%, \mathrm{p}<0.001)$. Hospital stay were also significantly longer for surgery procedure than transcatheter closure ( 8 days vs 3 days, $\mathrm{p}<0.0001$ ), and all surgical subjects required intensive care. Transcatheter closure had median total cost of Rp. 55.032.636 as compared to Rp. 58.593.320 for surgical procedure ( $\mathrm{p}=0.923)$. Conclusion. Perimembrane VSD transcatheter closure had similar efficacy and costs compared to surgical closure, with lower rate of complications as well shorter duration of hospital stay. Sari Pediatri 2015;17(1):9-16.

Keywords: perimembrane VSD, comparison, transcatheter septal occluder, surgery

Alamat korespondensi: Dr. Liku Satriani, Sp.A. RSIA Melania. Jl. Pahlawan No.91, Bogor, JABAR. E-mail: LikuSoegihardjo@gmail.com, likusatriani@idai.or.id 
Defek septum ventrikel (DSV) adalah penyakit jantung bawaan (PJB) yang berupa defek atau lubang pada sekat pembatas antara kedua bilik jantung dan terbanyak ditemui, yaitu sekitar $20 \%$ dari seluruh PJB pada anak. ${ }^{1,2}$ Sebelum era intervensi nonbedah diperkenalkan, metode pembedahan jantung merupakan satu-satunya tata laksana untuk semua jenis PJB, termasuk DSV. Pada lima dekade terakhir, tata laksana DSV telah mengalami perubahan yang cukup signifikan, terutama untuk DSV tipe muskuler dan perimembran. Penutupan DSV berbasis kateterisasi jantung sekarang telah menciptakan evolusi besar dalam tata laksana DSV, di samping tata laksana metode pembedahan. Penutupan DSV perimembran secara pembedahan sudah terbukti memberi hasil yang baik dengan angka mortalitas yang rendah. Namun demikian, komplikasi seperti blok atrioventrikular komplit (complete atrioventricular block/ cAVB), luka infeksi, komplikasi neurologi setelah pintas kardiopulmoner dari tindakan pembedahan ini masih merupakan masalah yang perlu diperhatikan. ${ }^{3}$

Metode penutupan secara trasnkateter ini sebagai alternatif tata laksana DSV perimembran selain pembedahan karena efektifitas cukup baik dan kurang invasif. Di samping itu, keuntungan metode ini adalah komplikasi yang terjadi selama dan segera setelah prosedur lebih sedikit. Secara kosmetik dan lama hari rawat, metode ini tidak meninggalkan sisa jaringan parut seperti pada metode pembedahan. Tata laksana komprehensif pada pasien DSV perimembran tidak hanya bertujuan untuk mengurangi angka mortalitas, morbiditas, dan biaya prosedur, tetapi juga untuk meningkatkan angka harapan dan kualitas hidup.

\section{Metode}

Penelitian dilaksanakan mulai bulan April 2014 sampai dengan Mei 2014 dengan pengambilan data penelitian berdasarkan rekam medik PJT RSCM. Pasien dengan diagnosis DSV perimembran lesi tunggal yang telah dilakukan prosedur penutupan DSV, baik secara transkateter maupun secara pembedahan dalam periode Januari 2010 - 31 Desember 2013. Diikutsertakan dalam penelitian data nama dan nomor rekam medis pasien diperoleh dari data harian tindakan di laboratorium kateterisasi jantung dan ruang operasi jantung PJT RSCM. Desain penelitian adalah retrospektif analitik, yang kemudian dilanjutkan dengan melakukan analisis perbandingan penutupan DSV metode transkateter dengan metode pembedahan, mencakup angka keberhasilan, komplikasi, lama rawat, dan biaya.

Subjek penelitian adalah sejumlah anak pada populasi terjangkau yang memenuhi kriteria inklusi dan eksklusi. Kami mengikutsertakan pasien dengan diagnosis DSV perimembran lesi tunggal yang telah dilakukan penutupan DSV, baik secara transkateter maupun pembedahan yang berusia antara 2-18 tahun dan atau berat badan $\geq 10 \mathrm{~kg}$. Kami tidak mengikutsertakan pasien DSV perimembran dengan hipertensi paru berat, DSV perimembran disertai kelainan jantung lain, usia $<2$ tahun dan $>18$ tahun saat dilakukan penutupan defek ,dan apabila data rekam medik tidak lengkap.

Teknik pengambilan sampel adalah consecutive sampling. Sampel yang diambil adalah semua data rekam medis dari pasien anak dengan DSV tipe perimembran atau muskuler yang datang berobat ke PJT RSCM dan telah dilakukan penutupan defek dengan metode pembedahan ataupun metode kateterisasi intervensi non-bedah dari Januari 2003-Desember 2013. Sampel yang memenuhi kriteria inklusi diambil sampai jumlah yang dibutuhkan terpenuhi. Luaran penelitian yang dianalisis adalah keberhasilan prosedur, komplikasi, efek samping, lama rawat di rumah sakit, lama rawat intensive care unit (ICU), dan total biaya.

Pengolahan data menggunakan program SPSS versi 11.5 dan perhitungan secara manual. Analisis deskriptif terhadap variabel yang ada dalam penelitian ini (distribusi, frekuensi, rerata atau median, dan proporsi) dilakukan dengan metode intention to treat analysis dengan menggunakan uji statistik parametrik dan non-parametrik. Untuk data pada kedua kelompok yang memiliki distribusi tidak normal digunakan uji perbandingan dengan uji Mann-Whitney. Analisis perbandingan hasil penutupan kedua metode dan kemungkinan potensi risiko komplikasi pada kedua kelompok dilakukan dengan metode uji chi-square. Ketepatan perhitungan menggunakan Interval Kepercayaan $95 \%$. Data dinyatakan dengan nilai tengah, simpang baku, rerata dan nilai $\mathrm{p}<0,05$ dianggap secara statistik bermakna.

\section{Hasil}

Proses pengambilan data dari rekam medik diperoleh 69 data, terdiri atas 39 pasien yang dilakukan penutupan DSV perimembran secara transkateter dan 30 pasien 
secara pembedahan untuk dianalisis lebih lanjut.

Pada kelompok transkateter digunakan berbagai jenis alat yang disesuaikan dengan ukuran defek. Alat yang digunakan selain AMVO, digunakan juga alat ADO I dan ADO II. Pada defek yang kecil digunakan juga nit occluder sebagai alat penutup defek. Nilai median lama fluoroskopi saat pemasangan alat adalah 44,08 menit (rentang 17,6-95,2 menit). Pada prosedur pembedahan, semua kasus menggunakan metode pembedahan konvensional (insisi midsternum) dan ditutup dengan patch. Nilai median lama pintasan jantung paru pada prosedur pembedahan adalah 51,50 menit (rentang 32-149 menit)

\section{Perbandingan hasil penutupan DSV perimembran antara kedua prosedur}

Pada prosedur transkateter, evaluasi hasil penutupan DSV perimembran dilakukan dalam dua tahap, yaitu segera setelah prosedur (immediately) dengan pemeriksaan TEE dan dalam 24 jam setelah prosedur atau sebelum pasien dipulangkan dengan pemeriksaan TTE, sedangkan pada prosedur pembedahan penilaian hasil penutupan dilakukan sebelum pasien dipulangkan atau jika didapatkan adanya klinis yang memerlukan penilaian lebih cepat.

Secara keseluruhan, keberhasilan kedua prosedur

Tabel 1. Karakteristik subjek penelitian

\begin{tabular}{lcc}
\hline Variabel & \multicolumn{2}{c}{ Jenis prosedur } \\
\cline { 2 - 3 } & Transkateter & Pembedahan \\
\hline Usia (tahun) $^{\mathrm{a}}$ & $5,9 \pm 2,8^{*}$ & $6(2-18)^{* *}$ \\
Jenis kelamin (\%) & & \\
$\quad$ Laki-laki & $24(61,5)$ & $17(56,7)$ \\
Perempuan & $15(38,5)$ & $13(43,4)$ \\
Berat badan (kg) & $16(11-42)^{* *}$ & $15,5(8-49)^{* *}$ \\
Tinggi badan $(\mathrm{cm})^{\mathrm{a}}$ & $107,2 \pm 17,7^{*}$ & $108,9 \pm 23,3^{*}$ \\
Status gizi (\%) & & \\
Lebih & $4(10,3)$ & $1(3,3)$ \\
Baik & $29(74,4)$ & $13(43,3)$ \\
Kurang & $3(7,7)$ & $10(33,3)$ \\
Buruk & $3(7,7)$ & $6(20)$ \\
Gejala klinis (\%) & & \\
Gangguan pertumbuhan & $16(41)$ & $20(66,7)$ \\
ISPA berulang & $12(30,8)$ & $23(76,7)$ \\
Komplikasi pra-prosedur (\%) & & \\
Gagal jantung & $13(33,3)$ & $20(66,7)$ \\
Hipertensi paru & $4(10,3)$ & $12(40)$ \\
\hline
\end{tabular}

Tabel 2. Karakteristik prosedur penutupan DSV perimembran metode transkateter dan pembedahan

\begin{tabular}{|c|c|c|c|}
\hline \multirow[t]{2}{*}{ Variabel } & \multicolumn{2}{|c|}{ Jenis prosedur } & \multirow[t]{2}{*}{ Nilai $p$} \\
\hline & Transkateter & Pembedahan & \\
\hline Ukuran defek $(\mathrm{mm})^{\mathrm{a}}$ & $3,4(2-9)$ & $10(1,5-20)$ & $<0,001^{c}$ \\
\hline Lama prosedur (menit) ${ }^{\mathrm{b}}$ & $155,6 \pm 43,5$ & $147,63 \pm 50,4$ & $0,484^{\mathrm{d}}$ \\
\hline Lama floroskopi (menit) ${ }^{\mathrm{b}}$ & $46,4 \pm 17,6$ & & \\
\hline Lama pintas jantung (menit) ${ }^{a}$ & & $51,50(32-149)$ & \\
\hline
\end{tabular}


dalam penutupan DSV perimembran tidak berbeda bermakna ( $\mathrm{p}=1,000$ dengan Fisher's exact). Evaluasi hasil penutupan DSV perimembran yang dilakukan saat kontrol rutin juga menunjukkan tidak ada pirau pada kedua prosedur.

\section{Perbandingan komplikasi penutupan DSV perimembran antara kedua prosedur}

Pada penelitian ini didapatkan kematian masingmasing 1 pasien pada kelompok prosedur transkateter $(2,6 \%)$ dan pembedahan $(3,33 \%)$. Pada kelompok prosedur transkateter, kematian dikarenakan terbentuknya trombus pasca-tindakan yang mengakibatkan gagal organ multipel, sedangkan pada kelompok pembedahan dikarenakan komplikasi infeksi pasca-prosedur. heparinisasi dan gangguan koagulasi (1 pasien), 1 kasus mengalami trombus yang mengakibatkan kematian. Sementara pada kelompok pembedahan, komplikasi yang timbul adalah infeksi (9 kasus), perdarahan (1 kasus), anemia (1 kasus), gangguan koagulasi (1 kasus), gagal jantung kongesti karena disfungsi LV (1 kasus), dan efusi pleura (1 kasus). Pemasangan drainase dilakukan pada 1 kasus dengan efusi pleura.

\section{Perbandingan lama rawat penutupan DSV per- imembran antara kedua prosedur}

Nilai median total lama rawat di rumah sakit pada kelompok transkateter adalah 3 hari (rentang 3-28 hari), sedangkan pada kelompok pembedahan adalah 8 hari (rentang 5-19 hari). Hasil uji hipotesis menunjukkan perbedaan yang bermakna antara kedua kelompok

Tabel 3. Perbandingan hasil penutupan DSV perimembran secara transkateter dan pembedahan

\begin{tabular}{lccc}
\hline Hasil akhir prosedur & \multicolumn{2}{c}{ Jenis prosedur } & Nilai $\mathrm{p}$ \\
\cline { 2 - 3 } & $\mathrm{Transkateter}$ & $\mathrm{P}$ & \\
& $\mathrm{n}=39$ & $\mathrm{n}=30$ & \\
\hline Berhasil (\%) & $35 / 39(89,7)$ & $29 / 30(96,7)$ & $0,271^{\mathrm{a}}$ \\
Gagal / Reintervensi (\%) & $3 / 39(7,7)$ & $0 / 30(0)$ & \\
Kematian (\%) & $1 / 39(2,6)$ & $1 / 30(3,33)$ & \\
\hline
\end{tabular}

${ }^{a}$ Uji Fischer's exact

Tabel 4. Perbandingan komplikasi penutupan DSV perimembran secara transkateter dan pembedahan

\begin{tabular}{lccc}
\hline \multirow{2}{*}{ Komplikasi prosedur } & \multicolumn{2}{c}{ Jenis prosedur } & \multirow{2}{*}{ Nilai $\mathrm{p}$} \\
\cline { 2 - 3 } & $\mathrm{T}$ Transkateter & Pembedahan $=30$ & \\
\hline Selama prosedur (\%) & $5 / 39(12,8)$ & $1 / 30(3,33)$ & $0,451^{\text {a }}$ \\
Pasca-prosedur (selama perawatan) (\%) & $3 / 39(7,7)$ & $14 / 30(46,7)$ & $<0,001^{\text {a }}$ \\
\hline
\end{tabular}

${ }^{a}$ Uji Fisher's exact

Komplikasi prosedur dapat terjadi, baik saat prosedur penutupan defek maupun selama perawatan atau pasca-prosedur. Selama prosedur penutupan defek, $3(7,9 \%)$ pasien mengalami bradikardia, tetapi berhasil di atasi dan prosedur dilanjutkan. Selama perawatan atau pasca-prosedur pada kelompok transkateter, dua dari 38 (5,3\%) pasien mengalami komplikasi, sedangkan pada kelompok pembedahan 14 dari 30 (46,7\%) pasien mengalami komplikasi.

Pada saat perawatan atau pasca-prosedur, komplikasi yang timbul pada kelompok transkateter adalah hilangnya pulsasi arteri dorsalis pedis (1 kasus), tetapi teratasi dengan prosedur, baik dalam hal lama rawat di ruang rawat biasa, lama rawat di ruang rawat intensif, maupun total lama rawat di rumah sakit. Hari rawat tertinggi selama 28 hari pada kelompok transkateter dan 19 hari pada kelompok pembedahan terjadi karena adanya 1 pasien dari tiap-tiap kelompok yang mengalami komplikasi berat yang meningkatkan jumlah hari lama rawat. Jika batas atas jumlah lama rawat dikeluarkan dari data maka akan diperoleh lama rawat rata-rata pasien DSV perimembran pasca-penutupan tanpa komplikasi untuk kelompok transkateter adalah 3 hari dan kelompok pembedahan 8 hari. 


\section{Perbandingan biaya penutupan DSV perimembran antara kedua prosedur}

Perhitungan total biaya prosedur, meliputi biaya sarana prosedur (biaya pemakaian ruang operasi atau ruang kateterisasi), biaya farmasi dan alat medis (obat, cairan infus, produk darah, dan termasuk biaya alat), biaya pemeriksaan penunjang (biaya pemeriksaan laboratorium, pemeriksaan radiologis, elektrokardiografi dan ekokardiografi), biaya ruang rawat (biaya ruang rawat biasa dan ruang rawat intensif), dan biaya jasa medis.

Pada kelompok transkateter didapatkan biaya farmasi dan alat medis yang tinggi dikarenakan alat penutup dimasukkan ke dalam biaya tersebut dan sampai saat ini harganya masih tinggi. Berdasarkan analisis data didapatkan kelompok transkateter mempunyai biaya pemeriksaan penunjang, biaya ruang rawat, dan biaya jasa medis yang lebih rendah dibandingkan dengan kelompok pembedahan $(\mathrm{p}<0,001)$. Namun, kelompok pembedahan mempunyai biaya farmasi $(\mathrm{p}<0,001)$ dan biaya sarana prosedur $(\mathrm{p}=0,015)$, yang lebih rendah dibandingkan dengan kelompok transkateter.

Jika alat penutup dikeluarkan, biaya farmasi pada kelompok prosedur transkateter lebih rendah dibandingkan kelompok pembedahan $(\mathrm{p}<0,001)$ dengan uji non parametrik Mann-Whitney. Demikian juga dengan total biaya pada kelompok transkateter juga menjadi lebih rendah dibanding dengan kelompok pembedahan dan bermakna secara statistik dengan $\mathrm{p}<0,001$.

Secara keseluruhan, kelompok transkateter mempunyai total biaya prosedur yang lebih rendah dibandingkan dengan kelompok pembedahan Rp. 55.032.636 vs Rp. 58.593.320, tetapi perbedaan ini tidak bermakna secara statistik $\mathrm{p}=0,923$. Perhitungan biaya di PJT RSCM merupakan perhitungan dengan sistem paket, sehingga biaya alat sudah termasuk dalam biaya farmasi dan alat medis.

\section{Pembahasan}

Penelitian ini bertujuan membandingkan hasil dan biaya penutupan DSV perimembran secara transkateter dan pembedahan pada pasien usia 2-18 tahun yang menjalani prosedur penutupan selama dalam perawatan. Keberhasilan penutupan DSV cukup tinggi dengan
89,7\% pada kelompok transkateter dan 96,7\% pada kelompok pembedahan. Tidak didapatkan perbedaan tingkat keberhasilan antara kedua prosedur. Publikasi lain menunjukkan tingkat keberhasilan prosedur transkateter yang sudah mulai meningkat, berkisar di angka 90\%-100\% dibandingkan dengan prosedur baku emas. ${ }^{4-6}$ Tiga pasien yang menjalani penutupan DSV perimebran secara transkateter mengalami kegagalan saat prosedur pemasangan alat. Satu pasien mengalami kesulitan penempatan alat AMVO no. 8 pada sisi ventrikel kiri VSD dan gagal melakukan crossing kembali. Satu pasien, setelah dikembangkan Heart Lifetech VSD symmetric no 08 pada VSD, didapatkan posisi yang tidak baik dan pirau residual besar sehingga prosedur dibatalkan. Satu pasien lainnya, setelah ditutup dengan ductal occluder device no 14-16 pada fase diastolik, didapatkan pirau residual besar sehingga diputuskan untuk membatalkan prosedur pemasangan. Ketiga pasien ini kemudian menjalani prosedur reintervensi pembedahan menggunakan patch dengan hasil yang baik.

Komplikasi prosedur penutupan DSV perimembran dapat timbul selama dan pasca prosedur. Pascaprosedur dibagi lagi menjadi segera setelah tindakan, selama perawatan, dan setelah keluar rumah sakit. Penelitian ini hanya dapat menganalisis komplikasi jangka pendek dari masing-masing prosedur yang meliputi komplikasi selama prosedur dilaksanakan serta pasca-prosedur segera dan selama perawatan.

Selama prosedur, pada kelompok transkateter didapatkan komplikasi berupa gangguan irama jantung, yaitu bradikardia dan takikardia ventrikel, serta perdarahan. Sementara di kelompok pembedahan didapatkan 1 kasus dengan komplikasi perdarahan yang membutuhkan transfusi komponen segera intra operasi. Komplikasi berupa gangguan irama jantung pada kelompok transkateter termasuk kategori komplikasi ringan yang dapat diatasi dengan manipulasi tindakan yang lebih baik. Gangguan irama jantung yang terjadi, kemungkinan akibat daerah ventrikel kanan dan arteri pulmoner terlalu sensitif sehingga manipulasi yang dilakukan di daerah tersebut dapat mengganggu konduksi listrik jantung. Sama halnya dengan laporan tindakan penutupan DSV perimembran secara transkateter di sentra negara lain yang melaporkan adanya gangguan irama jantung berupa right bundle branch block (RBBB) yang bersifat sementara. ${ }^{7}$ Demikian juga dengan komplikasi perdarahan pada pasien dalam kelompok 
pembedahan, sebaiknya digali lebih dalam apakah ada kondisi pre-operasi yang dapat mengganggu jalannya prosedur, seperti infeksi dan gangguan koagulasi. Pada laporan penelitian mengenai hasil penutupan DSV perimembran secara pembedahan disebutkan adanya komplikasi perdarahan yang memerlukan tindakan resternotomi untuk tata laksana perdarahan yang terjadi. ${ }^{8,9}$

Komplikasi berat yang timbul segera setelah prosedur ditemukan pada kelompok transkateter. Kasus dengan DSV perimembran $2 \mathrm{~mm}$, tidak terjadi komplikasi selama prosedur dan tindakan berjalan dengan lancar dan defek dapat ditutup sempurna dengan alat heart Lifetech symmetrical no 04. Selama prosedur, pemberian heparin 50 unit/ kgbb dan prosedur berlangsung selama 120 menit. Pasca prosedur, pasien mengalami penurunan kesadaran, diduga akibat trombus terlepas yang terjadi dalam proses tindakan penutupan secara transkateter. Pasien dirawat selama 28 hari di ICU PJT RSCM dan meninggal akibat gagal organ multipel. Pada kelompok pembedahan juga didapatkan dua komplikasi berat pasca-prosedur berupa sepsis. Pada satu kasus sepsis yang dialami menyebabkan gagal organ multipel yang berakibat kematian pada pasien tersebut, sedangkan satu kasus mengalami gagal respirasi yang memerlukan reintubasi dan pemakaian ventilator mekanik lebih lama.

Sebaliknya, komplikasi ringan didapatkan lebih banyak timbul pada kelompok pembedahan dibanding dengan kelompok transkateter, seperti infeksi, gagal jantung kongesti karena penurutan fungsi ventrikel kiri, anemia, gangguan koagulasi, perdarahan, dan efusi pleura. Pada kelompok transkateter didapatkan komplikasi ringan berupa hilangnya pulsasi arteri dorsalis pedis kanan pasca-prosedur yang dapat di atasi dengan pemberian heparin selama perawatan. Komplikasi pasca prosedur selama perawatan antara kelompok transkateter dan pembedahan berbeda. Perbedaan tersebut disebabkan komplikasi ringan yang terjadi lebih banyak pada kelompok pembedahan. Laporan serupa juga menggambarkan komplikasi yang timbul pada kelompok pembedahan lebih banyak. Jika komplikasi yang bersifat ringan diabaikan, tidak ada perbedaan dari segi komplikasi pada kedua jenis prosedur ini. ${ }^{4}$

Nilai median total lama rawat di rumah sakit pada kelompok transkateter adalah 3 hari (rentang 3-28 hari), sedangkan pada kelompok pembedahan adalah 8 hari (rentang 5-19 hari). Hasil uji hipotesis dari masing- masing variabel (lama rawat ICU, IW, biasa, dan Total lama rawat) menunjukkan perbedaan antara kedua kelompok prosedur, baik dalam hal lama rawat di ruang rawat biasa, di ruang rawat intensif, maupun total lama rawat di rumah sakit. Perbedaan hari rawat antara kelompok transkateter dan pembedahan disebabkan pada kelompok transkateter, apabila prosedur berjalan lancar tanpa disertai adanya komplikasi, pasien dapat dipulangkan satu hari setelah prosedur dilaksanakan dan tanpa harus melewati perawatan di ICU. Sementara pada kelompok pembedahan, perawatan di ICU merupakan tempat perawatan awal semua pasien pasca-pembedahan jantung terbuka. Hasil penelitian ini sesuai dengan penelitian lain yang menyebutkan lama rawat kelompok transkateter lebih singkat dibanding dengan kelompok pembedahan. . $^{5,610}$

Data biaya yang didapat adalah biaya yang ditagihkan kepada pasien setelah mendapatkan pelayanan, bukan perhitungan unit biaya berdasarkan clinical pathway yang sudah dibuat. Pada penelitian ini ditunjukkan biaya farmasi dan alat medis yang dibutuhkan pada prosedur transkateter lebih tinggi dibanding dengan prosedur pembedahan. Hal tersebut disebabkan oleh pembiayaan alat penutup di PJT RSCM dimasukkan ke dalam biaya farmasi. Peneliti berusaha untuk menganalisis secermat mungkin untuk mendapatkan kesimpulan yang mendekati kebenaran dengan cara mengeluarkan atribut alat terhadap biaya farmasi karena menurut data yang didapat peneliti, harga alat yang relatif besar memengaruhi total biaya farmasi secara keseluruhan. Dengan demikian, apabila biaya farmasi dikurangi dengan harga alat, akan diperoleh perbandingan yang terbalik dari perolehan sebelumnya. Hasil yang didapat menunjukkan biaya farmasi dari prosedur pembedahan lebih tinggi dibandingkan dengan biaya farmasi prosedur transkateter (rerata biaya farmasi tanpa alat untuk prosedur pembedahan Rp. 27.638.311,00 lebih besar dibanding prosedur transkateter Rp. 17.077.864,00). Biaya farmasi pada kelompok transkateter menjadi lebih rendah dibanding dengan kelompok pembedahan. Data juga menunjukkan adanya ketidaksamaan pengeluaran terhadap biaya farmasi. Pada setiap perhitungan pembiayaan tindakan dari kedua prosedur tersebut tidak berpedoman pada clinical pathway.

Biaya pada kelompok transkateter tidak seragam karena tidak semua prosedur transkateter memakai alat penutup yang sama. Perbedaan jenis alat penutup ini berpengaruh pada biaya keseluruhan karena tiap- 
tiap alat penutup memiliki harga yang berbeda. Alat penutup amplatzer memiliki harga tertinggi yaitu sebesar Rp. 36.300.000, sedangkan termurah adalah nit occluder yang berharga Rp. 14.399.000. Di PJT RSCM sejak Januari 2010 sampai dengan Desember 2013, prosedur transkateter menggunakan $A M V O$ pada 18 pasien, Lifetech 12 pasien, $A D O I$ dan $A D O$ $I I$ masing-masing 4 pasien dan dengan nit occluder 1 pasien.

Hasil rerata dan median masing-masing biaya total prosedur dengan alat yang berbeda juga menunjukkan total biaya yang tinggi berbanding lurus dengan harga alat penutup. Kecuali untuk prosedur yang memakai nit occluder yang memiliki biaya total lebih besar daripada rerata prosedur transkateter yang memakai $A D O I$. Namun, hal ini tidak dapat dibuktikan lebih jauh karena hanya satu prosedur yang menggunakan alat tersebut.

Pasien dengan prosedur transkateter dan pembedahan tidak berbeda pada biaya total. Hal yang dapat memengaruhi biaya total ini adalah biaya lain-lain yang tidak dapat diperhitungkan sebelumnya, seperti bertambahnya hari rawat, pindahnya pasien dari ruang ICU ke ruang perawatan biasa yang terbukti seperti pada penjelasan sebelumnya bahwa pada kelompok pembedahan memerlukan lama rawat lebih lama dibandingkan dengan prosedur transkateter. Adanya nilai tengah (median) menunjukkan bahwa semua tindakan masih belum mengikuti kaidah clinical pathway yang sudah dibuat oleh PJT RSCM. Hal tersebut dapat juga sebagai penyebab, kenapa terjadi perbedaan pada setiap tindakan yang seharusnya jika tindakan dilakukan sesuai dengan clinical pathway maka seharusnya tindakan tanpa komplikasi akan menghasilkan biaya total yang sama.

Jika variabel biaya alat dikeluarkan dari keseluruhan total biaya kelompok transkateter, maka akan diperoleh hasil median biaya total kelompok transkateter (Rp 28.209.348) yang lebih rendah dibandingkan dengan biaya total pada kelompok pembedahan (Rp. 58.593.320). Rentang yang cukup jauh pada kelompok transkateter (Rp. 13.316.394-166.618.823) karena ada satu pasien yang mengalami komplikasi berat yang memerlukan perawatan selama 28 hari di ICU pascaprosedur yang mengakibatkan pembengkakan total biaya keseluruhan. Beberapa penelitian yang dilakukan di pusat negara lain menunjukkan hasil perbandingan biaya total kelompok pembedahan yang lebih rendah dibanding dengan biaya total kelompok transkateter. ${ }^{5,6,10}$
Desain penelitian ini retrospektif analitik dan menggunakan data rekam medis pasien. Desain tersebut dipilih karena mempunyai kemampulaksanaan (feasibility) yang terbaik. Namun, karena bersifat retrospektif berdasarkan data yang terekam dalam rekam medis, beberapa variabel yang seharusnya bisa dianalisis lebih lanjut tidak dapat diperoleh.

\section{Kesimpulan}

Prosedur penutupan DSV perimembran secara transkateter mempunyai efektivitas dan biaya yang sama dengan prosedur pembedahan, tetapi mempunyai komplikasi yang lebih sedikit serta lama rawat di rumah sakit yang lebih pendek.

\section{Daftar pustaka}

1. Mullins CE. History of pediatric interventional catheterization: pediatric therapeutic cardiac catheterizations. Pediatr Cardiol 1998;19:3-7.

2. Kato H. Foreword: catheter interventional treatment for pediatric heart disease--a new therapeutic strategy. Pediatr Int 2001;43:527.

3. Mongeon FP, Burkhart HM, Ammash NM, Dearani JA, Li Z, Warnes CA, dkk. Indications and outcomes of surgical closure of ventricular septal defect in adults. JACC Cardiovasc Interv. 2010;3:290-7.

4. Oses P, Hugues N, Dahdah N, Vobecky SJ, Miro J, Pellerin M, dkk. Treatment of isolated ventricular septal defects in children: Amplatzer versus surgical closure. Ann Thorac Surg 2010;90:1593-8.

5. Xunmin C, Shisen J, Jianbin G, Haidong W.Lijun W. Comparison of results and complications of surgical and amplatzer device closure of perimembranous ventricular septal defects. Int J Cardiol 2007;120:28-31.

6. Liu S, Chen F, Ding X, Zhao Z, Ke W, Yan Y, dkk. Comparison of results and economic analysis of surgical and transcatheter closure of perimembranous ventricular septal defect. Eur J Cardiothorac Surg 2012;42:e15762.

7. Thanopoulos BD, Tsaousis GS, Karanasios E, Eleftherakis NG.Paphitis C. Transcatheter closure of perimembranous ventricular septal defects with the Amplatzer asymmetric ventricular septal defect occluder: preliminary experience in children. Heart 2003;89:918-22.

8. Bol-Raap G, Weerheim J, Kappetein AP, Witsenburg 
M.Bogers AJ. Follow-up after surgical closure of congenital ventricular septal defect. Eur J Cardiothorac Surg 2003;24:511-5.

9. Chen JM.Mosca RS. Surgical management of ventricular septal defects Progress in Pediatr Cardiol 2001;14:187-
97.

10. Zeinaloo AA MS, Zanjani KS, Mirzaaghayan MR. Device occlusion versus surgery for closure of congenital heart defects : cost issues in Iran. J Teh Univ Heart Ctr 2008;3:141-4. 